\title{
Adoption Level of Integrated Farming System Based on Rice-Cattle and Its Determinants Related to Sustainable Agriculture
}

\author{
Novitri Kurniat $i^{1, *}$, Ketut Sukiyono ${ }^{2}$, Purmini Purmini ${ }^{3}$, and Mutyarsih Oryza Sativa ${ }^{4}$ \\ ${ }^{1}$ Faculty of Agriculture, Department Agribussiness, University of Muhammadiyah Bengkulu, \\ Jl. Bali, Bengkulu 38119, Indonesia \\ ${ }^{2}$ Faculty of Agriculture, Department of Agricultural Social Economics, University of Bengkulu, \\ Jl. Kandang Limun, Bengkulu 38119, Indonesia \\ ${ }^{3}$ Faculty of Economics and Business, Department of Development Economics, University of \\ Bengkulu, Jl. Kandang Limun, Bengkulu 38119, Indonesia \\ ${ }^{4}$ Faculty of Agriculture, Department of Animal Science, Khonkaen University, 123 Moo 16 \\ Mittraphap Road, Khon kaen 40002, Thailand
}

\begin{abstract}
A way to restore the fertility of rice fields is through improving soil structure and microbes by using organic fertilizer derived from livestock waste. Therefore it is necessary to implement an Integrated Farming System (IFS) particularly rice and cattle. The study aimed to analyze the determinants of farmers' decisions in adopting IFS of rice in Bengkulu Province, Indonesia. This research applied a survey method, which was conducted in Seluma and Rejang Lebong Regencies, Bengkulu Province, Indonesia. The data included primary and secondary and analyzed with the use of Multinomial Logistic Regression. The results indicated that simultaneously all the predictor variables had a significant effect on the response variable, while the income, land area, number of cattle and farmers' perceptions had a very significant effect on the adoption of the integration system while the variable costs of production, farming experience and labor did not have a significant effect on the decision to adopt a rice and cattle integration system.
\end{abstract}

Keyword: Farmer perception, organic fertilizer, plant crop system

\section{Introduction}

The role of the agriculture sector in Bengkulu Province is also adequately strategic where nearly $60 \%$ of the productive workforce works in the agricultural sector and this sector redounds $39.84 \%$ in the Bengkulu Province Gross Domestic Product, Indonesia [1]. Rice is the backbone of the development of the food crops sub-sector and enact an important role in achieving food security.

The rate of increase in rice productivity in Bengkulu tends to be stationer, indicated by an alleviation in rice production of around $2.28 \%$ [1]. The rice intensification system that has been implemented but it has no longer increased production. This situation is due to a less integrated way of managing land and violating the rules of land conservation and the

\footnotetext{
* Corresponding author : noviewin@gmail.com
} 
environment. Intensive and continuous exploitation of rice fields affect declined soil fertility and physical properties due to lack of organic materials.

A way to remediate soil fertility is through improving soil structure and microbes by using organic fertilizer derived from livestock waste. To overcome the problems faced by most rice farmers, it is necessary to implement the IFS which combines rice and cattle.

Cattle still becomes a farmer income source in rural areas, where cows as a superior cattle commodity by most farmers in Bengkulu province. The high interest in raising cattle due to suitable natural conditions that has been a priority to support the development of the livestock sector.

According to Al Mamun, et al. [2] the problem faced by farmers in generally practice subsistence farming are high degree of risk because of seasonal, environmental and decreasing productivity. Integrated Farming System (IFS) can eradicate these constraints. Meanwhile, in accordance with Wibawa and Silviani [3], a new crop integration system was adopted by farmers in Bengkulu. Practically, the implementation of the IFS has not yet attained the target due to the limited assistance and technology dissemination, as well as farmers' views or perceptions about the IFS which is still low. Therefore, a study is needed of what factors affect the decision of farmers to adopt rice's IFS in Bengkulu Province. This study aimed to analyze the determinants of farmers' decisions in adopting IFS based on rice-cattle in Bengkulu Province.

\section{Methods}

This study employed the Survey method that takes samples from a population and used questionnaires as a primary data collection tool [4].

The study was conducted from January to July 2019. The study located in the Province of Bengkulu included the lowland area in Seluma Regency and the highland areas in Rejang Lebong Regency, Indonesia. The data included primary data from farmers and secondary data from relevant agencies.

The sampling method applied the Simple Random Sampling technique with a sample size as much as ten times of the independent variables number in each study area [4]. In this study, the number of samples taken was 200 rice farmers who raised cattle.

Data analyzing techniques employed Multinomial Logistics Regression [5], with the following Equation (1):

$\mathrm{INT}=\log \frac{p(x i) p(x i)}{1-p(x i) 1-p(x i)}$ bo $+\mathrm{b} 1 P i+\mathrm{b} 2 B P+\mathrm{b} 3 L L+\mathrm{b} 4 \mathrm{Put}+\mathrm{b} 5 J T k+\mathrm{b} 6 P+\mu$

Explanation :

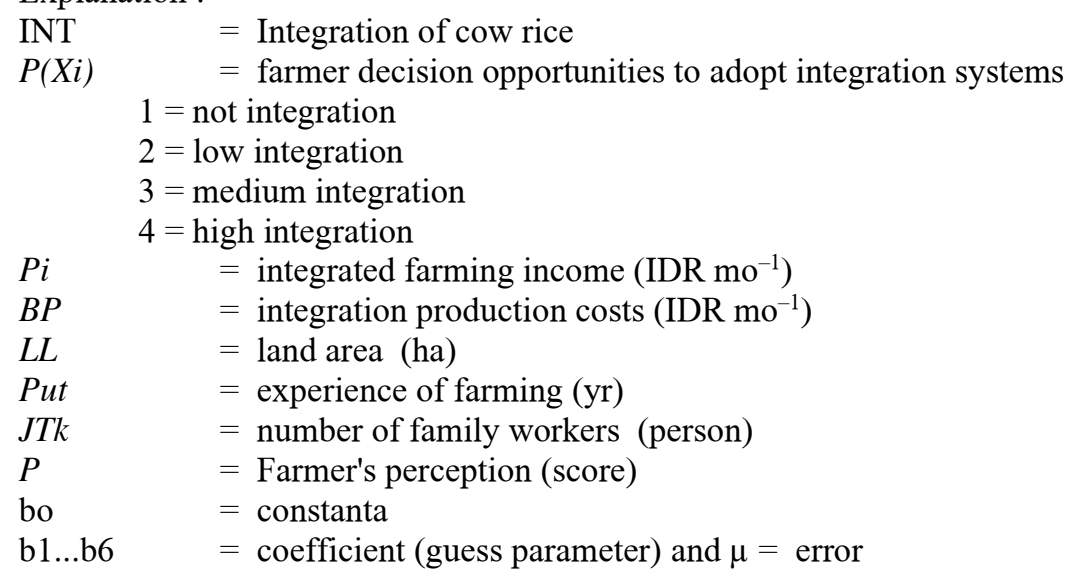


Parameter testing was enforced simultaneously and partially. The test statistic employed was to use Odds Ratio and Likelihood Ratio.

\section{Results and discussions}

\subsection{Factors that predispose farmers' decisions to adopt a cattle rice integration system}

The model that used to analyze the factors swaying the decision of farmers to adopt rice's IFS is the Multinomial Logistic Regression Analysis Model. The dependent variable (Y) used is the farmer's decision to adopt IFS in the form of nominal data with four categories, namely non, low, medium, and high integration respectively. While the independent variable $(\mathrm{X})$ used are seven variables, videlicet farm income, production costs, land area, number of cows, farming experience, the number of workers in the family and farmers' perceptions.

\subsection{Model conformity test}

Model testing implemented the goodness-of-fit test to like the compatibility of different models, or there was no difference between the observations with the model of outcome prediction. Table of Goodness-of-fit for testing the suitability model are provided in Table 1.

Table 1. Model conformance test output from goodness-of-fit table values

\begin{tabular}{|l|l|l|}
\hline & Chi-Square & Sig \\
\hline Pearson & 374.154 & 1.000 \\
\hline Deviance & 326.400 & 1.000 \\
\hline
\end{tabular}

Source: Data processed by SPSS 16 (2019)

Based on Table 1, it found that the Sig value of Pearson and the Deviance Sig was similar as 1.000 , implied that the model is fit to apply to outcome prediction because $\mathrm{p}$ value $>\alpha ;(1.000>0.01)$. In addition, the value of Deviance $(326.400)<$ Chi-Square table (497.199) then H0 was accepted, indicating that the model is suitable even though no significant difference between the observations and the possible predictions of the model.

\subsection{Model determination coefficient}

The model suitability test is carried out by looking at the value of the coefficient of determination listed on the Pseudo R-Square. From Table 2, the Nagelkerke R2 value was 0.650 which identified the variable variability of income, production costs, land area, number of cattle, farming experience, labor and perceptions able to explain the variability of integration system adoption decisions by $65 \%$, while the remaining $35 \%$ is explained by other variables outside the model.

Table 2. Model suitability test from the pseudo r-square table value

\begin{tabular}{|l|c|}
\hline Nagelkerke & 0.650 \\
\hline
\end{tabular}

Source: Data Processed by SPSS 16 (2019) 


\subsection{Simultaneous parameter estimation testing}

Simultaneous testing is performed using the likelihood ratio test as presented in Table 3.

Table 3. Simultaneous parameter estimation test

\begin{tabular}{|l|l|l|l|l|}
\hline & \multicolumn{4}{|l|}{ Likelihood Ratio test } \\
\hline Model & $-2 \log$ likehood & Chi-square & Sig. & Decision \\
\hline Intercept & 508.944 & & & Reject Ho \\
\hline Final & 326.400 & 182.543 & $0.000^{* *}$ & Accept H1 \\
\hline
\end{tabular}

Source: Data Processed by SPSS 16 (2019).

Information : $\alpha=0.01=42.98$

$\mathrm{Df}=24$

** = significant at $99 \%$ confidence level

Based on Table 3, it can be cross checked that the Final Sig. value is 0.000 . Test criteria are if the Sig. $(0.000)<\alpha(0.01)$ or X2 count $>\mathrm{X} 2$ table then its decision rejected $\mathrm{H} 0$ and accepted H1. It means income variable (X1), farming production costs (X2), land area (X3), number of cattle (X4), farming experience (X5), labor (X6) and farmers' perception (X7) simultaneously very significant effect on $(p<0.01)$ the decision of farmers to adopt the integration system (Y).

\subsection{Partial variable estimation testing}

Partial test results shown in Table 4 that it recognized partially four predictor variables i.e. income (X1), land area (X3), number of Cows (X4) and farmers' perceptions (X7), that it significantly affected on adoption decision variables system integration (Y), while three other variables namely production costs (X2), experience (X5), and the number of labor (X6) have no significant effect on the adoption of the integration system decision.

Table 4. Partial variable estimation test

\begin{tabular}{|c|c|c|c|c|}
\hline & $\begin{array}{l}\text { Likelihood } \\
\text { Ratio Test }\end{array}$ & & & \\
\hline Variabel & -2 likelihood & $\begin{array}{l}\text { Chi- } \\
\text { square }\end{array}$ & Sig. & Decision \\
\hline Intercept & $3.264 \mathrm{E} 2$ & 0.000 & & \\
\hline Income (X1) & 345.451 & 19.051 & $0.000 * *$ & Reject Ho Accept H1 \\
\hline Production cost (X2) & 333.127 & 6.727 & 0.081 & Reject Ho Accept H1 \\
\hline Land area $(\mathrm{X} 3)$ & 342.098 & 15.698 & $0.001 * *$ & Reject Ho Accept H1 \\
\hline Number of Cows (X4) & 343.612 & 17.211 & $0.001 * *$ & Reject Ho Accept H1 \\
\hline Experience (X5) & 332.865 & 6.464 & 0.091 & Reject Ho Accept H1 \\
\hline Labor (X6) & 328.628 & 2.228 & 0.527 & Reject Ho Accept H1 \\
\hline Perception (X6) & 382.441 & 56.040 & $0.000 * *$ & Reject Ho Accept H1 \\
\hline
\end{tabular}

Source: Data processed by SPSS 16 (2019).

The effect of each predictor variable on the response variable can be explained as follows:

i. Income $(\mathrm{X} 1)$

In the income variable, it is gained value X2 count $>\mathrm{X} 2$ table or $19.051>11.34$ and also Sig. $<\alpha$ or $0.000<0.01$, then, the decision taken is to reject Ho and Accept $\mathrm{H} 1$ meaning that farm income partially has a very significant effect on the decision to adopt a system of integration of rice and cattle. 
One of the motives of farmers in adopting new technologies is viewed from the income acquired from these new technologies. If the income obtained is greater, then, it will encourage farmers to adopt something new [6].

Several studies have indicated that the integration of livestock crops are able to increase farmers' incomes. The benefit of productivity improvement by $30 \%$ to $50 \%$ depending upon the number and kind of livestock products [7]. Besides that, Lindawati, et al [8] research's demonstrates that integrated farming income has a significant effect on the decisions of farmers' households in adopting integration system. This is in line with the research of Soni et al. [9] and Jaishankar, et al, [10] who show that the analysis of costs and benefits and farm income affect the decision to adopt a livestock crop integration system.

ii. Production Cost (X2)

Production costs is the cost spent on rice farming and cattle farming. In the production cost variable, it was obtained value X2-count $<$ X2-table or $6.727<7.815$ and Sig. $>\alpha$ or $0.081>0.01$, then the decision taken is H0 is accepted and H1 is rejected. This means that the production cost has a partially insignificant effect on the decision to adopt a rice and cattle integration system.

iii. Land area size (X3)

In the land area variable, it gained the value of X2-count $>\mathrm{X} 2$-table or $15.689>11.34$ and Sig. $<\alpha$ or $0.001<0.01$, then the decision taken is Ho is rejected and H1 is accepted. This means that the land area partially has a very significant effect on the decision to adopt an integrated rice and cattle system. This is because the more extensive rice fields cultivated, the more straw can be used to feed cattle. Farmers in the study area averagely cultivate 0.7 ha of rice land per farmer household.

Menozzi's research [11] suggests that the decision to adopt innovations by farmers is affected by many factors including farmer's attitude. The perception and adoption of the integration system is affected by, among others, socioeconomic factors including respondent's age, educational background, benefits, farm size and perception $[12,13]$. Livestock-crop integration is an agricultural system that is characterized by close links between crop components and livestock in farming or in an area. The synergistic relationship produced allows livestock to provide high profits per unit area of land used besides providing fertilizer for plants.

iv. Number of Cows (X4)

In the number of cows variable, it is obtained the value of $\mathrm{X} 2$ count $>\mathrm{X} 2$ table or $17.211>11.34$ and Sig. $<\alpha$ or $0.001<0.01$, then the decision taken is Ho is rejected and $\mathrm{H} 1$ is accepted. This means that the number of cows partially has a very significant effect on the decision to adopt the integration system of rice and cattle. This is because livestock waste can be used in rice plants as compost made manure, and as biourine that is processed from cow urine, and straw can be used directly as cattle feed.

Initially, the motivation of the rice farmers to establish cattle was to get income from the cattle fattening business and obtain cattle tillers. With the increasing number of cattle being farmed, it encouraged farmers to process fecal and urine into compost and biourine used in rice plants. Currently in the study area, on average the farmers keep 4.8 cattle per farmer household.

According to Kariyasa and Pasandaran [14], rice farming combined with livestock or using manure is able to produce around $6.9 \%$ to $8.8 \%$ higher than partially managed rice farming without using manure. One hectare of rice fields capable of producing about $10 \mathrm{t}$ to $20 \mathrm{t}$ of straw (fresh weight at harvest and depending on season) and used for feeding one to two adult cattle throughout the year. With rice straw production of $5 \mathrm{t} \mathrm{ha}^{-1}$ per harvest to $8 \mathrm{tha}^{-1}$ per harvest can be given two to three adult cattles throughout the year. If the rice 
cropping pattern is two times a year, it means that it can fulfill the requirements for feeding four cattles throughout the year to six cattles throughout the year.

v. Farming Experience (X5)

Farming experience is the length of time a farmer has done farming activities. In the farming experience variable, it is obtained the value of $\mathrm{X}^{2}$ count $<\mathrm{X}^{2}$ table or $6.464<7.815$ and Sig. $>\alpha$ or $0.091>0.05$, then the decision taken is $\mathrm{H} 0$ is accepted and H1 is rejected. This means that the farming experience partially has insignificant effect on the decision to adopt an integrated system of rice and cattle.

vi. Labor (X6)

Labor is the number of workers in families owned by farm households that consist of wives, children or relatives who live in one house and are the responsibility of the farmers. In the labor variable, it is obtained value X2 count $<\mathrm{X} 2$ table or $2.222<7.815$ and Sig. $>\alpha$ or $0.527>0.05$, then the decision taken is H0 is accepted and H1 is rejected. This means that labor partially has insignificant effect on the decision to adopt an integrated system of rice and cattle. This is because at the location of the study the number of family workers was relatively small at an average of 3.56 people per household. Meanwhile, implementing an integrated system requires relatively more labor than non-integrated systems.

vii. Perception (X7)

Perception is the farmers' views of the integrated system of rice and cattle. The perception is assessed with a score of one for low perception, two for medium perception, and three for high perception. In the number of cattle variables, it is obtained the value X2 count $>\mathrm{X} 2$ table or $56.040>16.81$ and Sig. $<\alpha$ or $0.000<0.01$, then the decision taken is Ho is rejected and H1 is accepted. This means that farmers' perceptions partially have a very significant effect on the decision to adopt a rice and cattle integration system.

Measurement of farmers' perceptions is carried out to know the effectiveness of an innovation that has been applied by farmers. Perception arises after the farmers implement farming integration systems and further can affect the adoption process of integration. Farmers' perceptions of the rice and cattle integration are viewed from the aspects of i) relative superiority, ii) suitability, iii) complexity, iv) can be tried, and v) can be observed [15].

The results showed that 34 farmers had low perception, 122 farmers had medium perception and 44 farmers had high perception of the integration system. On average farmers' perceptions at the research location are at a medium level.

\subsection{Model interpretation}

Model interpretation is carried out by considering the value of Exp (B) which is the value of the odds ratio in the SPSS output. In this study, four categories were used for the dependent variable, namely the category of no integration, low integration, medium integration, and high integration. One of the categories must be used as a reference variable. In this research, the category of no integration is used as a reference variable.

Table 5. Model interpretation results Parameter Estimation

\begin{tabular}{|l|l|l|l|l|l|l|}
\hline Decision & Variabel & B & SE & Wald & Sig & Exp (B) \\
\hline \multirow{3}{*}{$\begin{array}{l}\text { Low } \\
\text { Integration }\end{array}$} & Interception & 3.559 & 1.059 & 11.21 & 0.001 & \\
\cline { 2 - 7 } & Income & 0.000 & 0.000 & 0.349 & 0.555 & 1.000 \\
\cline { 2 - 7 } & Prod. cost & 0.000 & 0.000 & 1.046 & 0.306 & 1.000 \\
\cline { 2 - 7 } & Land area & 0.415 & 0.486 & 0.728 & 0.394 & 0.661 \\
\cline { 2 - 7 } & Number of cows & 0.389 & 0.143 & 7.415 & $0.006^{*}$ & 0.678 \\
\cline { 2 - 7 } & Farming experience & -0.005 & 0.023 & 0.052 & 0.819 & 0.995 \\
\hline
\end{tabular}

(Continued on next page) 
Tabel 5. Continued

\begin{tabular}{|c|c|c|c|c|c|c|}
\hline Decision & Variabel & B & SE & Wald & Sig & $\operatorname{Exp}(B)$ \\
\hline \multirow{4}{*}{$\begin{array}{l}\text { Low } \\
\text { Integration }\end{array}$} & Labor & -0.178 & 0.169 & 1.115 & 0.291 & 0.837 \\
\hline & Perception $=$ low & 3.332 & 0.997 & 11.169 & $0.001 *$ & 0.036 \\
\hline & Perception $=$ medium & 1.815 & 0.841 & 4.657 & $0.031 *$ & 0.163 \\
\hline & Perception $=$ high & $10^{\mathrm{b}}$ & & & & \\
\hline \multirow{10}{*}{$\begin{array}{l}\text { Medium } \\
\text { integration }\end{array}$} & Interception & 2.777 & 1.114 & 6.217 & 0.13 & \\
\hline & Income & 0.000 & 0.000 & 4.890 & $0.027 *$ & 1.000 \\
\hline & Prod. cost & 0.000 & 0.000 & 4.956 & $0.026^{*}$ & 1.000 \\
\hline & Land area & 1.701 & 0.555 & 9.406 & $0.002 *$ & 0.182 \\
\hline & Number of cows & 0.576 & 0.185 & 9.742 & $0.002 *$ & 0.562 \\
\hline & Farming experience & -0.045 & 0.030 & 2.237 & 0.135 & 0.956 \\
\hline & Labor & -0.004 & 0.191 & 0.000 & 0.985 & 0.996 \\
\hline & Perception $=$ low & 3.910 & 1.348 & 8.415 & $0.004 *$ & 0.020 \\
\hline & Perception $=$ medium & 2.416 & 0.878 & 7.575 & $0.006^{*}$ & 0.089 \\
\hline & Perception $=$ high & $0^{\mathrm{b}}$ & & & & \\
\hline \multirow{10}{*}{$\begin{array}{l}\text { High } \\
\text { integration }\end{array}$} & Interception & -4.942 & 4.381 & 1.272 & 0.259 & \\
\hline & Income & 0.000 & 0.000 & 8.101 & $0.004 *$ & 1.000 \\
\hline & Prod. cost & 0.000 & 0.000 & 3.517 & 0.061 & 1.000 \\
\hline & Land area & 3.718 & 1.421 & 6.850 & $0.009 *$ & 0.024 \\
\hline & Number of cows & 1.229 & 0.560 & 4.815 & $0.028^{*}$ & 0.293 \\
\hline & Farming experience & 0.109 & 0.081 & 1.817 & 0.178 & 1.115 \\
\hline & Labor & 0.522 & 0.742 & 0.496 & 0.481 & 1.686 \\
\hline & Perception = low & -22.282 & 0.000 & - & - & $2.1 \times 10^{-10}$ \\
\hline & Perception $=$ medium & -24.742 & 7658.4 & 0.000 & 0.997 & $1.8 \times 10^{-11}$ \\
\hline & Perception $=$ high & $0^{\mathrm{b}}$ & & & & \\
\hline
\end{tabular}

Reference category: No Integration

Source: Data processed, 2019.

From the table of parameter estimation results above, there are three multinomial logit models formed. All three models have independent variables that have a statistically significant effect.

i. Multinomial logit 1 equation (Comparison between Low Integration category ( $\mathrm{Y}=2)$

and No Integration $(\mathrm{Y}=1)$ Equation (2):

$\operatorname{Ln}(\mathrm{P} 2 / \mathrm{P} 1)=3.559+0.000 X 1+0.000 X 2+0.415 X 3+0.389 X 4-0.005 X 5-$

$$
0.178 X 6+0.332 X 7 R+1.815 X 7 S
$$

The coefficient value of the cow numbers $(X 4)$ is significant at $\alpha 0.05$. The coefficient value is 0.389 and $\operatorname{Exp}(\mathrm{B})$ is 0.678 which means that more cows have 0.678 times chance to adopt a low level integration system than not integration.

The low and medium coefficient value of farmer's perception $(X 7 R$ and $X 7 S)$ is significant at $\alpha 0.05$. The coefficient value is 3.332 and $\operatorname{Exp}(\mathrm{B})$ is 0.036 , and the coefficient value is 1.815 and $\operatorname{Exp}(\mathrm{B})$ is 0.163 which means low and medium perception have the opportunity of 0.036 and 0.163 times to adopt a low level integration system compared to no integration system.

ii. Multinomial logit two equation (Comparison between the Medium Integration category

$(\mathrm{Y}=3)$ and No Integration $(\mathrm{Y}=1)$ Equation (3)

$\operatorname{Ln}(\mathrm{P} 3 / \mathrm{P} 1)=2.777+0.000 X 1+0.000 X 2+1.701 X 3+0.576 X 4-0.045 X 5-$

$$
0.004 X 6+3.910 X 7 R+2.416 X 7 S
$$

The coefficient of income $(X 1)$ is statistically significant at $\alpha 0.05$. The coefficient value is 0.000 and $\operatorname{Exp}(\mathrm{B})$ is 1.000 , which means the higher farm income, the opportunity to do a medium level integration system is 1.000 times compared to no integration. 
The coefficient of production cost $(X 2)$ is statistically significant at $\alpha 0.05$. The coefficient value is 0.000 and $\operatorname{Exp}(\mathrm{B})$ is 1.000 , which means that the higher the production cost, the opportunity to do a medium level integration system is 1.000 times compared to no integration.

The land area size coefficient value $(X 3)$ is statistically significant at $\alpha 0.05$. The coefficient value is 1.701 and $\operatorname{Exp}(\mathrm{B})$ is 0.182 , which means that the larger land area size has a 0.661 times opportunity to adopt a medium level integration system than no integration.

The low and medium coefficient value of farmers' perception $(X 7 R$ and $X 7 S)$ is significant at $\alpha 0.05$. The coefficient value is 3.910 and $\operatorname{Exp}(\mathrm{B})$ is 0.020 and the coefficient value is 2.416 and Exp (B) is 0.089 which means low and medium perception have an opportunity of 0.020 times and 0.089 times to adopt a medium level integration system compared to no integration system.

iii.Multinomial logit three equation (Comparison between the High Integration category

$(\mathrm{Y}=4)$ and No Integration $(\mathrm{Y}=1)$ Equation (4)

$\operatorname{Ln}(\mathrm{P} 4 / \mathrm{P} 1)=-4.942+0.000 X 1+0.000 X 2+3.718 X 3+1.229 X 4+0.109 X 5+$ $0.522 X 6-22.282 X 7 R-24.742 X 7 S$

The coefficient of income $(X 1)$ is statistically significant at $\alpha 0.05$. The coefficient value is 0.000 and $\operatorname{Exp}(\mathrm{B})$ is 1.000 , which means the higher farming income, the opportunity to do a high level integration system is 1.000 times compared to no integration.

The land area size coefficient value (X3) is statistically significant at $\alpha 0.05$. The coefficient value is 3.718 and $\operatorname{Exp}(\mathrm{B})$ is 0.024 , which means the larger land area size has 0.024 times the opportunity to adopt a high level integration system rather than no integration.

The coefficient value of the cow numbers $(X 4)$ is statistically significant at $\alpha 0.05$. The coefficient value is 1.292 and $\operatorname{Exp}(\mathrm{B})$ of 0.293 which means that the more cow numbers has 0.293 times the opportunity to adopt a higher level of integration system than not integration.

\section{Conclusion}

In conclusion, this study indicated that simultaneously all the predictor variables had a significant effect on the response variable, while the income, land area, number of cattle and farmers' perceptions had a very significant effect on the adoption of the integration system while the variable costs of production, farming experience and labor did not have a significant effect on the decision to adopt a rice and cattle integration system.

\section{References}

1. Biro Pusat Statistik. Bengkulu Dalam Angka. Bengkulu (2017). https://bengkulu.bps.go.id/publication/2017/08/11/e3f44cfdc2b9cf36c2891704/provinsibengkulu-dalam-angka-2017.html

2. S. A. Mamun, N. Fouzia, R.D. Momota. J. Environ. Sci Natural Res., 4,2:127-136 (2011). https://www.banglajol.info/index.php/JESNR/article/view/10161

3. Wibawa, Wahyu dan Silviyani. Sistem Pertanian Bioindustri yang Berkelanjutan Berbasis Integrasi Padi - Sapi. BPTP. Bengkulu. (2015).p.121. [in Bahasa Indonesia]

4. K. Sukiyono. Penelitian Survai dan Teknik Sampling. Badan Penerbitan Fakultas Pertanian UNIB. Bengkulu. (2018).p.233. [in Bahasa Indonesia]

5. A.M. El-Habil. Pakistan J. Stat. Oper. Res. 8,2:271-291(2012) https://www.researchgate.net/publication/274394043_An_Application_on_Multinomial _Logistic_Regression_Model 
6. B. Situmorang, S. Edwina, E. Maharani. Jurnal Online Mahasiswa Fakultas Pertanian Universitas Riau. 2,1:1-12(2015). [in Bahasa Indonesia].

https:/www.neliti.com/id/publications/200956/adopsi-inovasi-petani-kelapa-sawitterhadap-sistem-integrasi-sapi-kelapa-sawit-s

7. S. B. Manjunatha, D. Shivmurthy, A. S. Sunil, M. V. Nagaraj, K. N. Basavesha,. J. Agr. Allied Sci. 3,4:30-38(2014)

https://www.researchgate.net/publication/272158685_Research_and_Reviews_Journal of_Agriculture_and_Allied_Sciences_Integrated_Farming_System_An_Holistic_Appro ach_A_Review

8. Lindawati. Analisis Faktor yang Mempengaruhi Perilaku Ekonomi dan Kesejahteraan Rumahtangga Petani Usahatani Jawa Barat [Analysis of Factors Affecting the Economic Behavior and Welfare of Farm Farmers in West Java]. [Thesis Phd]. Institut Pertanian Bogor (2017).p.140. [in Bahasa Indonesia]. https://repository.ipb.ac.id/jspui/bitstream/123456789/85350/1/2017lin.pdf

9. R.P. Soni, K. Mittu, L. Rajesh, IOSR J. Agricul Veterinary Sci. 7,10:36-42(2014) https://pdfs.semanticscholar.org/3a42/2fb51a31a8c1dbe60e34b5db68e16294b149.pdf

10. N. Jaishankar, B.S. Janagoudar, K. Basavaraj, V. P. Naik, S. Siddayya. Integrated Farming for Sustainable Agriculture and Livelihood Security to Rural Poor. International Conference on Chemical, Biological and Environmental Science. May 12-13. Kuala Lumpur. Malaysia (2014).p22-24

https://www.researchgate.net/publication/282148497_Integrated_Farming_for_Sustaina ble_Agriculture_and_Livelihood_Security_to_Rural_Poor

11.D. Menozzi, M. Fioravanzi, M. Donati. BAE . 4,2:125-147(2015). https://www.researchgate.net/publication/282133518_Farmer's_motivation_to_adopt_su stainable_agricultural_practices

12. S. Patidar dan H. Patidar. Int. J. Appli. Innov Eng. Manag. 4,3:269-277(2015) https://www.ijaiem.org/Volume4Issue3/IJAIEM-2015-03-31-91.pdf

13. S.D. Argade, G. Sankhala, S. Wadkar. Int. J. Agr. Ext. 03,1:25-30(2015). https://www.researchgate.net/publication/277773800_International_Journal_of_Agricul tural_Extension_FARMER'S_PERCEPTION_TOWARDS_INTEGRATED_FARMIN G_SYSTEMS_IN_MAHARASHTRA_A_METHODOLOGICAL_APPROACH

14. K. Kariyasa, Y. A. Dewi. J. Int. Food Agric. Econ. 1,2:29-38(2013) https://www.researchgate.net/publication/283715033_Analysis_of_factors_affecting_ad option_of_integrated_crop_management_farmer_field_school_IcmFfs_in_swampy_areas

15. E.M. Rogers. Diffusion of Innovation. The Free Press. New York (2004).p.576. https://books.google.co.id/books/about/Diffusion_of_Innovations_5th_Edition.html?hl= $\underline{\mathrm{id} \& \mathrm{id}=9 \mathrm{U} 1 \mathrm{~K} 5 \mathrm{LjUOwEC} \& \text { redir_esc }=\mathrm{y}}$ 